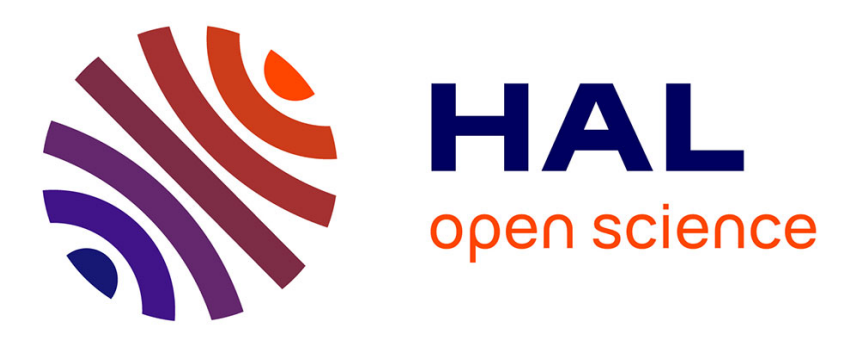

\title{
Interpenetrated Constitutional Networks of Aromatic Metallosupramolecular Duplexes
}

Yves-Marie Paul Legrand, Florina Dumitru, Arie van Der Lee, Mihail Barboiu

\section{To cite this version:}

Yves-Marie Paul Legrand, Florina Dumitru, Arie van Der Lee, Mihail Barboiu. Interpenetrated Constitutional Networks of Aromatic Metallosupramolecular Duplexes. Supramolecular Chemistry, 2009, 21 (03-04), pp.230-237. 10.1080/10610270802478271 . hal-00513542

\section{HAL Id: hal-00513542 \\ https://hal.science/hal-00513542}

Submitted on 1 Sep 2010

HAL is a multi-disciplinary open access archive for the deposit and dissemination of scientific research documents, whether they are published or not. The documents may come from teaching and research institutions in France or abroad, or from public or private research centers.
L'archive ouverte pluridisciplinaire HAL, est destinée au dépôt et à la diffusion de documents scientifiques de niveau recherche, publiés ou non, émanant des établissements d'enseignement et de recherche français ou étrangers, des laboratoires publics ou privés. 


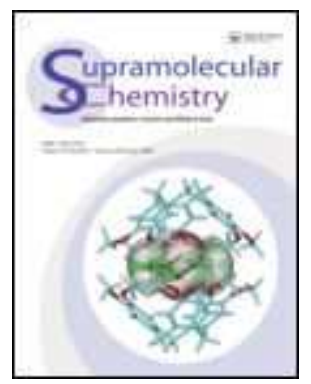

\section{Interpenetrated Constitutional Networks of Aromatic Metallosupramolecular Duplexes}

\begin{tabular}{|c|c|}
\hline Journal: & Supramolecular Chemistry \\
\hline Manuscript ID: & GSCH-2008-0078.R1 \\
\hline Manuscript Type: & Full Paper \\
\hline $\begin{array}{r}\text { Date Submitted by the } \\
\text { Author: }\end{array}$ & 26-Aug-2008 \\
\hline Complete List of Authors: & $\begin{array}{l}\text { Legrand, Yves-Marie; Institut Europeen des Membranes } \\
\text { Dumitru, Florina; Institut Europeen des Membranes } \\
\text { van der Lee, Arie; Institut Europeen des Membranes } \\
\text { Barboiu, Mihail; Institut Européen des Membranes }\end{array}$ \\
\hline Keywords: & $\begin{array}{l}\text { metallosupramolecular complexes, imine, self-assembly, aromatic } \\
\text { interactions }\end{array}$ \\
\hline \multicolumn{2}{|c|}{$\begin{array}{l}\text { Note: The following files were submitted by the author for peer review, but cannot be converted } \\
\text { to PDF. You must view these files (e.g. movies) online. }\end{array}$} \\
\hline $\begin{array}{l}2 Z n 2 . \text { cif } \\
3 Z n 2 . c i f \\
4 Z n 2 . c i f \\
\text { Scheme1a.cdx } \\
\text { Scheme1b.cdx } \\
\text { Scheme1c.cdx }\end{array}$ & \\
\hline
\end{tabular}

\section{ScholarONE \\ Manuscript Central}




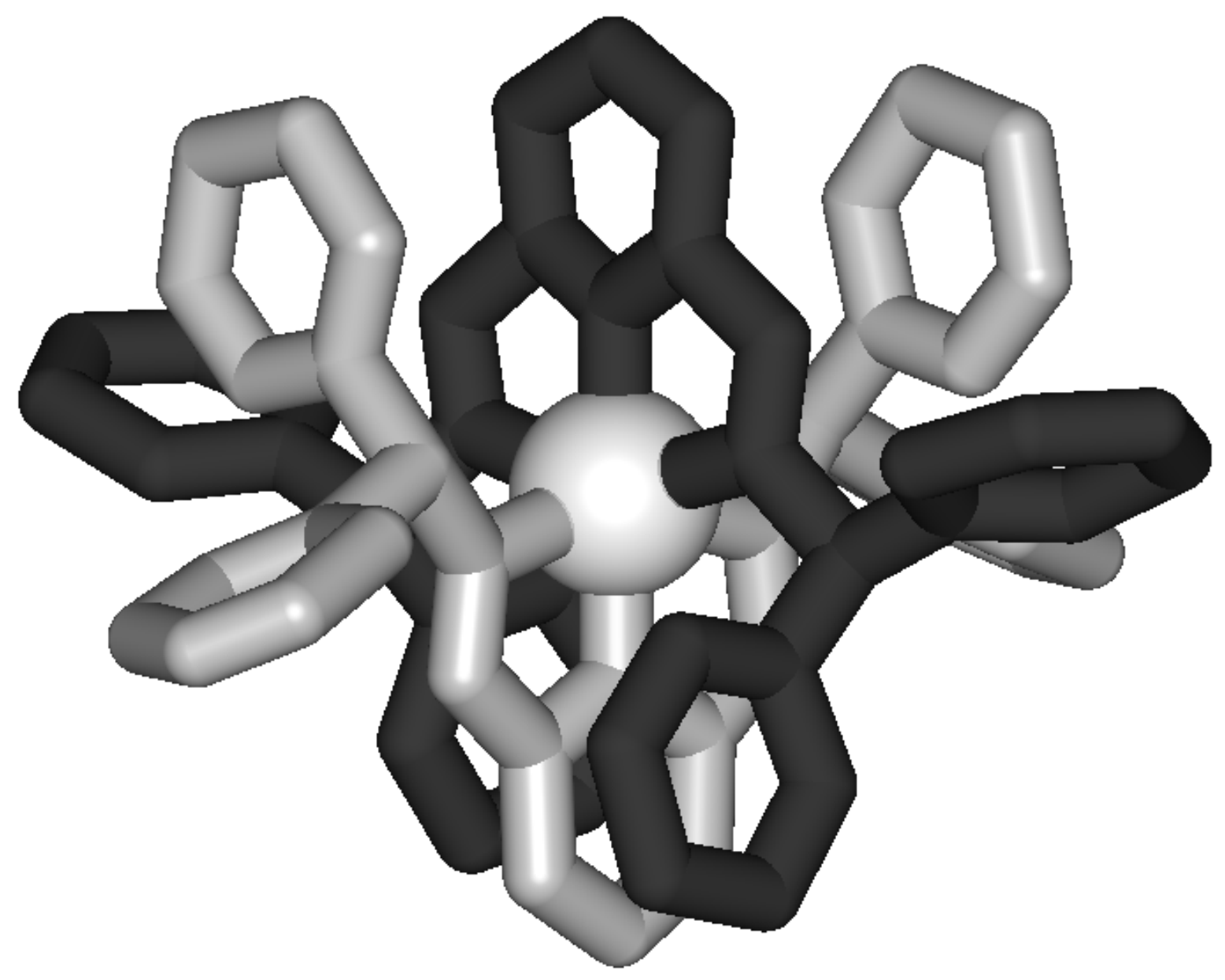




\title{
Interpenetrated Constitutional Networks of Aromatic
}

\section{Metallosupramolecular Duplexes}

\author{
Y.-M. LEGRAND ${ }^{\mathrm{a}}$, F. DUMITRU ${ }^{\mathrm{a}, \mathrm{b}}$, A. V. D. LEE ${ }^{\mathrm{a}} \&$ M. BARBOIU ${ }^{\mathrm{a}, *}$ \\ ${ }^{a}$ Institut Européen des Membranes, Adaptive Supramolecular Nanosystems Group - ENSCM- \\ UMII-CNRS UMR- 5635, Place Eugène Bataillon, CC 047, F-34095 Montpellier, Cedex 5, \\ France, ${ }^{b}$ University "Politehnica" of Bucharest, Department of Inorganic Chemistry, 1 , \\ Polizu st., RO-011061 Bucharest, Romania ${ }^{1}$
}

\begin{abstract}
We report hierarchical supramolecular organization promoted by the formation of metallosupramolecular duplex architectures. 3D supramolecular structure propagation is favoured by long-range aromatic-aromatic interactions toward robust double-helical configuration in $1_{2} \mathrm{Zn}^{2+}$, tubular squared architecture in $2_{2} \mathrm{Zn}^{2+}$ and selforganized triangles in $4_{2} \mathrm{Zn}^{2+}$. The advantageous structural features of such external aromatic interactions are not preserved while introducing new variables such as methylene spacer between imine moiety and the aromatic rings, inducing a orthogonal spatial orientation of the peripheral aromatic arms in $3_{2} \mathrm{Zn}^{2+}$. Indeed, the introduction of supplementary aromatic functionality in $4_{2} \mathrm{Zn}^{2+}$, results in the combination of both internal and external forces and has led to metallosupramolecular triangle architectures that are stabilized by 3D "diphenylmethane embrace motifs". The homochiral triangles connected via tetrahedral nodes and face-to-face triangle interactions are organized in the crystal that each duplex constituent has an alternate opposite chirality
\end{abstract}

Keywords: metallosupramolecular complexes, imine, self-assembly, aromatic interactions

Corresponding author. E-mail: mihai.barboiu@iemm.univ-montp2.fr 


\section{INTRODUCTION}

Molecular self-organisation is the basis for the construction of new useful synthetic materials in a bottom-up strategy. The way from molecular to nano(micro)-scale systems depend both on the nature of its constituents and on the interactions between them.[1-4]. The self-organization exploits non-covalent interactions in a multitude of ways and implements sets of molecules containing specific information stored in the arrangement of specific binding sites. The selection of one or more supramolecular architectures occurs as function of either internal (such as the nature and the geometry of the binding subunits, the composition, etc.) or external factors (such as the nature of the medium, the presence of specific molecules or anions, etc). Metal-directed self-assembly [3-5] or combined hydrogen-bonding-metal coordination [6] and $\pi-\pi$ stacking-metal coordination [7] supramolecular interactions has been extensively used as a powerful tool for the spontaneous generation of such nanostructures.

We have recently reported the double helical complex $\mathbf{1}_{2} \mathrm{Zn}^{2+}$ (Fig.1a) which after being left to stand for some hours produced homochiral crystals containing only one of $\Delta$ and $\Lambda$ mirror enantiomers. [8] In the crystal of $\mathbf{1}_{2} \mathrm{Zn}^{2+}$ each duplex of one helical sense is $\pi-\pi$ stacked with two duplexes of the same helical sense (Fig.1b). This pattern generates double helix stacks of $\mathbf{1}_{2} \mathrm{Zn}^{2+}$ units. In the crystal the adjacent columns of one helical sense run in parallel directions and interweave the peripheral phenyl and pyridine rings which are in van der Waals contact in a one-over/one-under fashion (Fig.1c). This generates a gearwheels-type mechanism with a very uncommon topology such that each double helix is in van der Waals contact with four neighbouring ones of the same helical sense.

A set of interconverting $\Delta$ and $\Lambda$ mirror enantiomers of $\mathbf{1}_{2} \mathrm{Zn}^{2+}$ units represents a constitutional dynamic library [8c, d] in solution. After some hours, single-crystals started to form in the acetonitrile/i-propylether system and resolved homochiral metallosupramolecular domains of unique helicity had been amplified through a phase-change driven selection 
process. [8d] Constitutional affinity drives the selection of interdigitated homochiral doublehelical architectures under internal pressure of the 3D long range multiscrew-type interactions (Fig.1d). Weak aromatic interactions, stabilize such supramolecular assemblies by $\pi$-stacking and van der Waals aromatic interactions and constitute the driving force of the homochiral crystal phase cohesion.

Figure 1 here

Scheme 1 here

To obtain systematic insights into the creation of these architectures interacting via peripheral aromatic groups which are responsible for the constitutional communication between homochiral double-helical columns within the 3D crystalline space, we investigated new similar systems by combining metal-ion coordination with weak aromatic-aromatic interactions. As a step towards this goal, it is of interest to investigate whether changes in expression of the crystal packing can be modulated by considering outer structural factors, by introducing different aromatic substituents on the peripheral surface. One possible presumption is to consider that the additional supramolecular aromatic interactions like in biphenyl-type compound $\mathbf{2}$ or different spatial orientation of phenyl moiety like in the benzyltype compound $\mathbf{3}$ or supplementary hydrophobic interactions in the bisphenylmethane-type compound 4 might direct the constitutional organisation of the crystalline frameworks by controlling the supramolecular connectivity between the ligands of the metallosupramolecular duplexes $\mathbf{2}_{2} \mathrm{Zn}^{2+}, \mathbf{3}_{2} \mathrm{Zn}^{2+}$ and $\mathbf{4}_{2} \mathrm{Zn}^{2+}$ (Scheme 1).

\section{EXPERIMENTAL SECTION}

Materials and Methods: 2,6-pyridinedicarboxaldehyde was prepared by oxidation of 2,6-pyridinemethanol with activated $\mathrm{MnO}_{2}$ according to the procedure described in the literature [11a]. 4-aminobiphenyl, benzylamine, benzhydrylamine were purchased from 
Synthesis of ligands 1-4: Ligand 1 [11] and 3 [12] were synthesised as previously described.

Ligand 2 - has been synthesized in EtOH by condensation of 2,6-pyridinedicarboxaldehyde $(0.1 \mathrm{~g}, 0.74 \mathrm{mmol})$ with 4-aminobiphenyl $(0.25 \mathrm{~g}, 1.48 \mathrm{mmol})$, under reflux for $12 \mathrm{~h}$ with constant stirring. After solvent evaporation, the resulting crude material was recrystallized from acetonitrile to give 2 as a light-yellow solid, $(0.275 \mathrm{~g}, 85 \%)$. F.M. $\mathrm{C}_{31} \mathrm{H}_{23} \mathrm{~N}_{3}$, $\mathrm{MW}=437.55 \mathrm{~g} / \mathrm{mol} .{ }^{1} \mathrm{H}-\mathrm{NMR}\left(300 \mathrm{~Hz}, \mathrm{CDCl}_{3}, \mathrm{ppm}\right): \delta=8.769(\mathrm{~s}, 2 \mathrm{H}, \mathrm{CH}=\mathrm{N}), 8.347-8.321$ $\left(\mathrm{d}, 2 \mathrm{H}, \mathrm{H}^{\mathrm{b}}, J=7.8 \mathrm{~Hz}\right), 8.005-7.952\left(\mathrm{t}, 1 \mathrm{H}, \mathrm{H}^{\mathrm{a}}, J=7.8 \mathrm{~Hz}\right), 7.696-7.632\left(\mathrm{~m}, 8 \mathrm{H}, \mathrm{H}^{\mathrm{c}+\mathrm{d}}\right), 7.488-$ $7.338\left(\mathrm{~m}, 10 \mathrm{H}, \mathrm{H}^{\mathrm{arom}}\right)$. MS (ESI): m/z (100\%): $438.25\left(2-\mathrm{H}^{+}\right)$.

Ligand 4: - has been synthesized in EtOH by condensation of 2,6-pyridinedicarboxaldehyde $(0.1 \mathrm{~g}, 0.74 \mathrm{mmol})$ with benzhydrylamine $(0.27 \mathrm{~g}, 1.48 \mathrm{mmol})$, under reflux for $12 \mathrm{~h}$ with constant stirring. After solvent evaporation, the resulting crude material was recrystallized from acetonitrile to give 4 as a white solid, (0.310 g, 90\%). F.M. $\mathrm{C}_{33} \mathrm{H}_{27} \mathrm{~N}_{3}, \mathrm{MW}=465.59$ g/mol. ${ }^{1} \mathrm{H}-\mathrm{NMR}\left(300 \mathrm{~Hz}, \mathrm{CDCl}_{3}, \mathrm{ppm}\right): \delta=8.530(\mathrm{~s}, 2 \mathrm{H}, \mathrm{CH}=\mathrm{N}), 8.273-8.248\left(\mathrm{~d}, 2 \mathrm{H}, \mathrm{H}^{\mathrm{b}}\right.$, $J=7.5 \mathrm{~Hz}), 7.848-7.796\left(\mathrm{t}, 1 \mathrm{H}, \mathrm{H}^{\mathrm{a}}, J=7.8 \mathrm{~Hz}\right), 7.404-7.217\left(\mathrm{~m}, 20 \mathrm{H}, \mathrm{H}^{\mathrm{ar}}\right), 5.700(\mathrm{~s}, 2 \mathrm{H}, \mathrm{CH})$. MS (ESI): m/z (100 \%): $466.29\left(4-\mathrm{H}^{+}\right)$. 
Synthesis and single crystal structures of $1_{2} \mathrm{Zn}^{2+}-4_{2} \mathrm{Zn}^{2+}$ complexes. The reactions were performed typically on a $10 \mathrm{mg}$ scale of ligand. The ligands $\mathbf{1 - 4}$ and $\mathrm{Zn}\left(\mathrm{CF}_{3} \mathrm{SO}_{3}\right)_{2}$ were dissolved in $\mathrm{CD}_{3} \mathrm{CN}(1 \mathrm{~mL})$, and stirred overnight at $60{ }^{\circ} \mathrm{C}$. Layering such solutions duplex complexes $\mathbf{1}_{2} \mathrm{Zn}^{2+}-\mathbf{4}_{2} \mathrm{Zn}^{2+}$ in acetonitrile with the $i$-propylether at room temperature, resulted in a unique set of single-crystals suitable for X-ray single-crystal experiments.

Compound $1_{2} \mathrm{Zn}^{2+}:{ }^{1} \mathrm{H}-\mathrm{NMR}\left(\mathrm{CD}_{3} \mathrm{CN}, \mathrm{ppm}\right): \delta=8.82(\mathrm{~s}, 4 \mathrm{H}, \mathrm{CH}=\mathrm{N}), 8.60-8.55\left(\mathrm{t}, 2 \mathrm{H}, \mathrm{H}^{\mathrm{a}}\right.$, $J=7.8 \mathrm{~Hz}), 8.27-8.24\left(\mathrm{~d}, 4 \mathrm{H}, \mathrm{H}^{\mathrm{b}}, J=7.8 \mathrm{~Hz}\right), 7.38-7.25\left(\mathrm{~m}, 12 \mathrm{H}, \mathrm{H}^{\mathrm{ar}}, J=8.7 \mathrm{~Hz}\right), 6.91-6.88(\mathrm{~d}$, $\left.8 \mathrm{H}, \mathrm{H}^{\mathrm{ar}}, \mathrm{J}=3.35 \mathrm{~Hz}\right)$. ES-MS: m/z (\%): 317.7 (100)

Compound $2_{2} \mathrm{Zn}^{2+}:{ }^{1} \mathrm{H}-\mathrm{NMR}\left(\mathrm{CD}_{3} \mathrm{CN}, \mathrm{ppm}\right): \delta=8.901(\mathrm{~s}, 4 \mathrm{H}, \mathrm{CH}=\mathrm{N}), 8.626-8.574(\mathrm{t}, 2 \mathrm{H}$, $\left.\mathrm{H}^{\mathrm{a}}, J=7.8 \mathrm{~Hz}\right), 8.297-8.271\left(\mathrm{~d}, 4 \mathrm{H}, \mathrm{H}^{\mathrm{b}}, J=7.8 \mathrm{~Hz}\right), 7.631-7.414\left(\mathrm{~m}, 32 \mathrm{H}, \mathrm{H}^{\mathrm{d}}+\mathrm{H}^{\mathrm{ar}}, J^{d-c}=8.4 \mathrm{~Hz}\right)$, 6.923-6.895 (d, 8H, H $\left.\mathrm{H}^{\mathrm{c}}, J^{c-d}=8.4 \mathrm{~Hz}\right)$. ES-MS: m/z (\%): $469.46(100)$

Compound $3_{2} \mathrm{Zn}^{2+}:{ }^{1} \mathrm{H}-\mathrm{NMR}\left(\mathrm{CDCl}_{3}, \mathrm{ppm}\right): \delta=8.62-8.58\left(\mathrm{t}, 2 \mathrm{H}, \mathrm{H}^{\mathrm{a}}, J=7.8 \mathrm{~Hz}\right), 8.05(\mathrm{~s}, 2 \mathrm{H}$, $\mathrm{CH}=\mathrm{N}), 7.85-7.80\left(\mathrm{~d}, 2 \mathrm{H}, \mathrm{H}^{\mathrm{b}}\right), 7.20-7.10\left(\mathrm{t}, 2 \mathrm{H}, \mathrm{H}^{\mathrm{ar}}\right), 7.05-6.95\left(\mathrm{t}, 4 \mathrm{H}, \mathrm{H}^{\mathrm{ar}}\right), 6.65-6.55(\mathrm{~d}, 4 \mathrm{H}$, $\left.\mathrm{H}^{\mathrm{arom}}\right), 4.60\left(\mathrm{~s}, 8 \mathrm{H}, \mathrm{CH}_{2}\right) . \mathrm{ES}-\mathrm{MS}: \mathrm{m} / \mathrm{z}(\%): 373.7(100)$

Compound $4_{2} \mathrm{Zn}^{2+}:{ }^{1} \mathrm{H}-\mathrm{NMR}\left(\mathrm{CD}_{3} \mathrm{CN}, \mathrm{ppm}\right): \delta=8.244-8.192(\mathrm{t}, 2 \mathrm{H}, J=7.8 \mathrm{~Hz}), 7.935 / 7.927 *$ (s, 4H, CH=N), 7.692-7.666 (d, 4H, J=7.8 Hz), 7.210-7.112 (m, 40H, $\left.\mathrm{H}^{\mathrm{ar}}\right), 5.548 / 5.540 *(\mathrm{~s}$, 4H, CH). ES-MS: m/z (\%):497.54 (100).* atropisomerism at room temperature see text.

\section{X-ray Single Crystal Diffraction Data for $1_{2} \mathrm{Zn}^{2+}-5_{2} \mathrm{Zn}^{2+}, 1_{2} \mathrm{Fe}^{2+}$ and $1_{2} \mathrm{Co}^{2+}$ complexes:}

The diffraction intensities were collected at the joint X-ray Scattering Service of the Institut Charles Gerhardt and the Institut Européen des Membranes of the University of Montpellier II, France, at $175 \mathrm{~K}$ using an Oxford Diffraction Xcalibur-I and a Gemini-S diffractometer. The crystal-to-detector distance was $50 \mathrm{~mm}$ for all five measurements. The structures were solved by direct methods using SIR2002 [13a] or by ab-initio (charge-flipping) methods using SUPERFLIP [13b] and refined by least-squares methods on F using CRYSTALS [13C], 
against $|F|$ on data having $I>2 \sigma(I) ; R$-factors are based on these data. Hydrogen atoms were partly located from difference Fourier synthesis, partly placed based on geometrical arguments, and in general not refined. Non-hydrogen atoms were in general refined anisotropically, except where the data to parameter ration did not allow doing this. Full details can be found in the cif-files and in Supplementary material.

Crystallographic data (excluding structure factors) for the structures reported in this paper have been deposited with the Cambridge Crystallographic Data Centre as supplementary publication no. CCDC-695886-695888. Copies of the data can be obtained free of charge on application to CCDC, 12 Union Road, Cambridge CB2 1EZ, UK (fax: (+44) 1223 336-033; email: deposit@ccdc.cam.ac.uk).

\section{RESULTS AND DISCUSSION}

The crystal structures of the complexes $\mathbf{2}_{2} \mathrm{Zn}^{2+}, \mathbf{3}_{2} \mathrm{Zn}^{2+}$ and $\mathbf{4}_{2} \mathrm{Zn}^{2+}$ were determined from crystals obtained from the acetonitrile/i-propylether solutions at room temperature. The molecular and the crystal packing structures are presented in Figures 2 and 3. In all duplex structures $\mathbf{2}_{2} \mathrm{Zn}^{2+}, \mathbf{3}_{2} \mathrm{Zn}^{2+}$ and $\mathbf{4}_{2} \mathrm{Zn}^{2+}$ the $\mathrm{Zn}^{2+}$ ions are fully coordinated by two ligands arranged into two orthogonal planes and present an octahedral coordination geometry (Fig. 2). The average $\mathrm{Zn}^{2+}-\mathrm{N}_{\text {Pyridine }} \mathrm{Zn}^{2+}-\mathrm{N}_{\text {imine }}$ and $\mathrm{Zn}^{2+}-\mathrm{N}_{\text {imine, }}$, distances are 2.05 or $2.24 \AA$, respectively.

\section{Figure 2 here}

The unit cell of $2_{2} \mathrm{Zn}^{2+}$ was found to contain six homoduplex complexes together with twelve triflate counterions. Overall the crystal structure is racemic and the duplexes are organized in parallel layers of $\Delta$ and $\Lambda$ mirror enantiomers which are alternatively stratified. Within a layer they are associated by two different sets of $\pi-\pi$ stacking interactions (Fig.3a).

Figure 3 here 
These aromatic stacking interactions are constitutionally different and allow in one direction the internal overlaps between the biphenyl-pyridine triads with the average centroidcentroid distances of 3.71 and $3.98 \AA$ corresponding to van der Waals contact. The terminal phenyl moiety of the biphenyl triad in further $\pi-\pi$ stacked with a similar one of the adjacent layer (the average centroid-centroid distance of $3.94 \AA$ ). In the other direction, each layer is alternatively stratified above each other by stacking only the terminal biphenyl moieties, such that each layer is in van der Waals contact (the average centroid-centroid distance of $4.10 \AA$ ). The square packing arrangement of duplex subunits results in the formation of a tubular structure with a hydrophobic hole of approximately $3 \AA$. The triflate anions are arranged into approximately linear array tightly fitting into the central cavity of the resulted tubular channels (Fig.3b).

\section{Figure 4 here}

As expected, the solution studies revealed that the introduction of the methylene spacer between the imine moiety and the terminal phenyl moieties dramatically change the spatial orientation of the phenyl moieties. The signals of the phenyl moieties of the complex $\mathbf{3}_{2} \mathrm{Zn}^{2+}$ were overall strongly shielded $(\Delta \delta=1.0)$ with respect to the ligand $\mathbf{3}$, suggesting strong intramolecular attractive $\pi-\pi$ stacking interactions between the phenyl and central pyridine moiety.

The unit cell of the complex $\mathbf{3}_{2} \mathrm{Zn}^{2+}$ was found to contain four duplex complexes together with eight triflate counterions. In the crystal the two ligands are strongly intertwined stabilizing the duplex superstructure by internal $\pi$ - $\pi$ stacking interactions (Fig. 2c). The relative position of the duplex ligands allows an internal overlap between the phenyl moieties and the central pyridine moiety with an average centroid-centroid distance of $3.9 \AA$ corresponding to a van der Waals contact. In the crystal the communication between duplexes $\mathbf{3}_{2} \mathrm{Zn}^{2+}$ is disrupted, each duplex being closely packed with the two neighbouring ones by 
weak van der Waals contacts (Fig. 4). It is useful to briefly emphasize the influence of the introduction of the methylene spacer which is clearly important for internal holding and stabilizing the duplex formation by the $\pi-\pi$ stacking. However the external $\pi-\pi$ stacking communication is completely removed and non-communicating duplex structures are present in the crystal structure. Overall the crystal structure is racemic and $\Delta$ and $\Lambda$ mirror enantiomers duplexes are closely packed via van der Waals contacts.

Compared with $\mathbf{1}_{2} \mathrm{Zn}^{2+}$ duplex with an intermediate orientation of the terminal phenyl rings allowing internal and external $\pi-\pi$ stacking interactions, the external aromatic interactions are completely suppressed in the $\mathbf{3}_{2} \mathrm{Zn}^{2+}$ framework and further substitution of the methylene moiety in $\mathbf{3}$ with a second phenyl moiety in ligand $\mathbf{4}$ would result in external structural communication between the multiaromatic duplexes $4_{2} \mathrm{Zn}^{2+}$.

The free rotation of the diphenylmethane groups around $\mathrm{CH}-\mathrm{N}$ bond is possible in cisoid-cisoid [5f] conformation of the ligand $\mathbf{4}$ and one singlet was identified in ${ }^{1} \mathrm{H}-\mathrm{NMR}$ spectrum. Two sets of singlet signals were identified in the regions of 7.9 and $5.5 \mathrm{ppm}$ of ${ }^{1} \mathrm{H}-$ NMR spectrum of $\mathbf{4}_{2} \mathrm{Zn}^{2+}$ for imine and $\mathrm{CH}$ protons, indicating a hindered rotation of the four diphenylmethane groups sterically very close to the neighbouring ones (see Fig. 2d) when $\mathbf{4}_{2} \mathrm{Zn}^{2+}$ duplexes form in the presence of the $\mathrm{Zn}^{2+}$ metal ions. On account of the hindered rotation of diphenylmethane groups around $\mathrm{CH}-\mathrm{N}$ bond in the $\mathbf{4}_{2} \mathrm{Zn}^{2+}$ duplex, the two sets of signals in the ${ }^{1} \mathrm{H}-\mathrm{NMR}$ spectrum can be assigned to the $\Delta$ and $\Lambda$ mirror atropenantiomers. (Supporting informations)

\section{Figure 5 here}

The unit cell of $\mathbf{4}_{2} \mathrm{Zn}^{2+}$ complex was found to contain sixteen duplex complexes together with thirty-two very disordered triflate counterions and filling the interstices between the duplexes so that all available space is filled. Symmetry expansion of the crystal cell of $\mathbf{4}_{2} \mathrm{Zn}^{2+}$ shows that the self-assembly of the duplex units form triangle-like trimers. Three 
duplexes of the same chirality are self-assembled into a metallosupramolecular triangle that is stabilized by a new three-dimensional "diphenylmethane embrace trimer" in which three Vshaped bisaromatic units fill their interstices so that their internal available space is filled (Fig. 5a). Aromatic embrace motifs are well documented for a series of aromatic clusters [10] and their significance in terms of interactions (for example stabilization energy of the benzene trimer is estimated to be $-20 \mathrm{KJ} / \mathrm{mol}$ ) is widely recognized [14]. Diphenylbenzene trimers formation in the solid state has been previously reported. [15] The diphenylmethane embrace trimerization in $\mathbf{4}_{2} \mathrm{Zn}^{2+}$ may contribute to the stabilization of such hierarchically selfassembled duplexes. The crystal structure is racemic. The homochiral triangles connected via tetrahedral nodes and face-to-face triangle interactions are organized in the crystal that each duplex constituent has an alternate opposite chirality (Fig 5b).

\section{CONCLUSION}

In conclusion we have demonstrated in this paper the synthesis of large solid state supramolecular crystalline superstructures stitched together from a combination of metalcoordination and weak $\pi-\pi$ stacking and van der Waals aromatic interactions. Hierarchical supramolecular organization is promoted by the formation of metallosupramolecular duplex architectures stabilized by internal $\pi-\pi$ stacking interactions and by long-range supramolecular spatial interactions between duplex systems via specific aromatic interactions. Long-range 3D supramolecular structure propagation is favoured via weak internal stacking interactions toward robust double-helical configurations in $\mathbf{1}_{2} \mathrm{Zn}^{2+}$, tubular squared packed architecture in $\mathbf{2}_{2} \mathrm{Zn}^{2+}$ and homochiral triangles in $\mathbf{4}_{2} \mathrm{Zn}^{2+}$. The advantageous structural features of such external interactions are not preserved while introducing new variables such as methylene spacer between imine moiety and phenyl groups, inducing a very different spatial orientation of the lateral aromatic arms in $\mathbf{3}_{2} \mathrm{Zn}^{2+}$. This configuration is clearly important for internal holding and stabilize the duplex formation by the $\pi-\pi$ stacking. 
However the external $\pi-\pi$ stacking interactions are completely removed and noncomunicating duplex structures are present in the crystal structure of $\mathbf{3}_{2} \mathrm{Zn}^{2+}$. Indeed, the introduction of supplementary aromatic functionality results in the combination of both internal and external forces and has led to metallosupramolecular triangle architectures that are stabilized by is stabilized by a new three-dimensional "diphenylmethane embrace motif".

The use of such multiple hierarchical aromatic interactions provide a very powerful tool and a target supramolecular platform for the stabilization of constitutional tertiary superstructures but also for a kind of modulable structure in the presence of external stimuli. Functional supramolecular devices for gas storage or catalysts are envisaged for the systems reported here and such studies are underway.

\section{Acknowledgements}

This work, conducted as part of the award "Dynamic adaptive materials for separation and sensing Microsystems" (M.B.) made under the European Heads of Research Councils and European Science Foundation EURYI (European Young Investigator) Awards scheme in 2004, was supported by funds from the Participating Organizations of EURYI and the EC Sixth Framework Program. See www.esf.org/euryi. This research was also supported in part by the ANR-06-Blan-0117 POLYFUNMAG Program and CNRS.

\section{References}

1. a) Lehn, J.-M. Supramolecular Chemistry-Concepts and Perspectives, VCH, Weinheim, 1995, pp124-138; (b) Lehn, J.-M. Proc. Natl. Acad. Sci. 2002, 99, 4763-4768.

2. J. Chem. Soc., Dalton Trans. 2000, 21, Special Issue on Crystal Engineering.

3. For recent reviews on metal ion metal self-assembly, see for exemple: (a) Leininger, S., Olenyuk; B., Stang, P.J. Chem. Rev. 2000, 100, 853-908; (b) Swiegers, G.F.; Malfetese, T.F. Chem. Rev. 2000, 100, 3483-3538; (c) Holliday, B.J.; Mirkin, C.A. Angew. Chem. 2001, 113, 2076-2097, Angew. Chem. Int. Ed., 2001, 40, 2022-2043. 
4. For recent reviews on metal hydrogen-bonding self-assembly, see for exemple: (a) Desiraju, G.R. Acc. Chem. Res., 2002, 35, 565-573 b) Lehn, J.-M. in Supramolecular Polymers, ed. Ciferi, A. Dekker, New York, NY, 2000, 615-641; (c) Archer, E.A.; Gong, H.; Krische, M. J. Tetrahedron 2001, 57, 1139-1159.

5. a) Schmuck, C. Angew. Chem. 2003, 115, 2552-2556, Angew. Chem. Int. Ed. 2003, 42, 2448-2451; b) OH, K.; Jeong, K.-S.; Moore, J. S. Nature 2001, 414, 889-893; c)

6. a) Braga, D.; J. Chem. Soc., Dalton Trans. 2000, 21, 3705-3713; b) Noveron, J.C.; Lah, M.S.; del Sesto, R.E.; Arif, A.M.; Miller, J.S.; Stang, P.S. J. Am.Chem. Soc. 2002, 124, 66136625; c) Uemura, K. S.; Kitagawa, M.; Kondo, K.; Fukui, R.; Kitaura, H. C.; Chang, T.; Mizutani, T. Chem. Eur. J. 2002, 8, 3587-3600; d) Tadokoro, M.; Kanno, H.; Kitajiama, T.; Shimada, H.; Nakanishi, N.; Isodobe, K.;. Nakasuji, K. Proc. Natl. Acad. Sci. 2002, 99, 49504995; e) Muthu, S.; Yip, J.H.K.; Vittal, J.J.; J. Chem. Soc., Dalton Trans. 2002, 23, 45614568 f) Barboiu, M.; Lehn, J.-M. Proc. Natl. Acad. Sci. USA 2002, 99, 5201-5206; g) Barboiu M.; Cerneaux, S.; van der Lee, A.; Vaughan, G. J. Am. Chem. Soc. 2004, 126, 3545-3550; h) Cazacu, A.; Tong, C.; van der Lee, A.; Fyles, T. M.; Barboiu, M. J. Am. Chem. Soc. 2006, 128, 9541-9548; i) Arnal-Herault, C.; Michau, M.; Pasc-Banu, A.; Barboiu, M. Angew. Chem. Int. Ed., 2007, 46, 4268-4272; (k) Arnal-Herault, C.; Pasc-Banu, A.; Michau, M.; Cot, D.; Petit, E.; Barboiu, M. Angew. Chem. Int. Ed. 2007, 46, 8409-8413; (1) Michau, M.; Barboiu, M.; Caraballo, R. Arnal-Hérault, C.; Periat P.; van der Lee, A.; Pasc, A. Chem. Eur.J., 2008, 14, 1776-1783 m) Barboiu, M.; Supuran, C.T.; Menabuoni, L. ; Scozzafava, A.; , Mincione, F.; Briganti, F.; Mincione, G. J. Enzymol. Inhib., 1999, 15, 23-46; n) Barboiu, M.; Guizard, C.; Hovnanian, N.; Palmeri, J.; Reibel, C.; Luca, C.; Cot, L. J. Membrane Sci., 2000, 172, 91103; o) Barboiu, M.; Guizard, C.; Luca, C.; Hovnanian, N.; Palmeri, J.; Cot, L. J. Membrane Sci, 2000,174, 277-286; p) Villamo, O.; Barboiu, C.; Barboiu, M.; Yau-Chun-Wan, W.; Hovnanian, N. J. Memb. Sci., 2002, 204, 97-110. 
7. a) Barboiu, M.; Lehn, J.-M. Revista de Chimie. 2006, 9, 909-914; b) Barboiu, M.; Vaughan, G.; Kyritsakas, N.; Lehn, J.-M. Chem. Eur J. 2003, 9, 763-769; c) Barboiu, M.; Petit, E.; Vaughan, G. Chem. Eur. J. 2004, 10, 2263-2270; d) Blondeau, P.; van der Lee, A.; Barboiu, M. Inorg. Chem. 2005, 44, 5649-5653 e) Barboiu, M.; Lehn, J.M. Revista de Chimie, 2008 $i 59(3), 255-259$.

8. a) Dumitru, F.; Petit, E.; van der Lee, A.; Barboiu, M. Eur. J. Inorg. Chem. 2005, 21, 42554262; b) Legrand, Y.M.; van der Lee, A.; Barboiu, M. Inorg. Chem. 2007, 46, 9540-9547; c) Lehn, J. M. Chem. Soc. Rev. 2007, 36, 151-160; d) Angelin, M.; Fischer, A. \& Ramstrom, O. J. Org. Chem. 2008, 73, 3593-3595.

9. Scudder, M.L.; Goodwin, H.A.; Dance, I.G. New J. Chem. 1999, 23, 695-705.

10. Lions F.; Martin, K. V. J. Am. Chem. Soc., 1957, 79(11), 2733-2738.

11. a) Vance, A.L.; Alcock, N.A.; Heppert, J.A.; Busch, D. H. Inorg.Chem. 1998, 37, 69126920; b) de Bruin, B.; Bill, E.; Bothe, E.; Weyhermüller, T.; Wieghardt, K. Inorg. Chem. 2000, 39, 2936-2947.

12. Creber, M.L.; Orrell, K.G.; Osborne, A.G.; Sik, V.; Bingham, A. L.; Hursthouse, M.B. J. Organomet. Chem. 2001, 631, 125-134.

13. a) Burla, M. C.; Camalli, M. B.; Carrozzini, G. L.; Cascarano, R.; Giacovazzo, C.; Polidori, G.; Spagna, R. J. Appl. Crystallogr., 2003, 36, 1103; (b) Betteridge, P. W.; Carruthers, J. R.; Cooper, R. I.; Prout, K.; Watkin, D. J. J. Appl. Crystallogr., 2003, 36, 1487. (c) Palatinus, L.; Chapuis, G. J. Appl. Cryst. 2007, 40, 786-790 14. Morimoto, T.; Uno, H.; Furuta, H. Angew. Chem. Int. Ed., 2007, 46, 3672-3675. 15. a) Kusukawa, T.; Fujita, M. J. Am. Chem. Soc. 2006, 124, 13576. b) Mislow, K. J. Org. Chem. 1981, 46, 4975; b) Precigoux, G.; Barrans, Y.; Busetta, B.; Marsau, P. Acta Crystallogr.,Sect.B: Struct. Crystallogr. Cryst. Chem. 1975, 31, 1497. 


\section{Figure caption}

FIGURE 1. From achiral ligands to metallosupramolecular homochiral double helical strands. a) Synthesis of $\mathbf{1}_{2} \mathrm{Zn}^{2+}$ duplex complexes; b) homochiral double helix stacks of $\mathbf{1}_{2} \mathrm{Zn}^{2+}$ units and c) crystal packing of double-helix columns: generation a gearwheels-type mechanism such that each double helix is in van der Waals contact with four neighbouring ones of the same helical sense.

FIGURE 2. Crystal structure in stick representation of the duplex complexes a) $\mathbf{1}_{2} \mathrm{Zn}^{2+}$, b) $\mathbf{2}_{2} \mathrm{Zn}^{2+}$, c) $\mathbf{3}_{2} \mathrm{Zn}^{2+}$ and d) $\mathbf{4}_{2} \mathrm{Zn}^{2+}$; the $\mathrm{Zn}^{2+}$ ions are shown as white spheres.

FIGURE 3 Crystal packing of the duplex complex $2_{2} \mathrm{Zn}^{2+}$ : a) side view in stick representation and enlarged details of the $\pi-\pi$ stacking interactions; b) The square packing arrangement of duplex subunits with the triflate anions in CPK representation filling the central cavity of the resulted tubular channels. The $\mathrm{Zn}^{2+}$ ions are shown as gray spheres.

FIGURE 4. Crystal packing in stick representation of the duplex complex $\mathbf{3}_{2} \mathrm{Zn}^{2+}$.

FIGURE 5 Crystal packing of the duplex complex $\mathbf{4}_{2} \mathrm{Zn}^{2+}$ : a) side view in CPK representation of triangle like trimers and enlarged details of the "diphenylmethane embrace motif"; b) The packing arrangement of homochiral triangle enantiomers: top view of tetrahedral nodes and side view in CPK representation of face-to- face triangle self-assembly.

SCHEME 1. Synthesis of $\mathbf{2}_{2} \mathrm{Zn}^{2+}, \mathbf{3}_{2} \mathrm{Zn}^{2+}$ and $\mathbf{4}_{2} \mathrm{Zn}^{2+}$ duplex complexes 

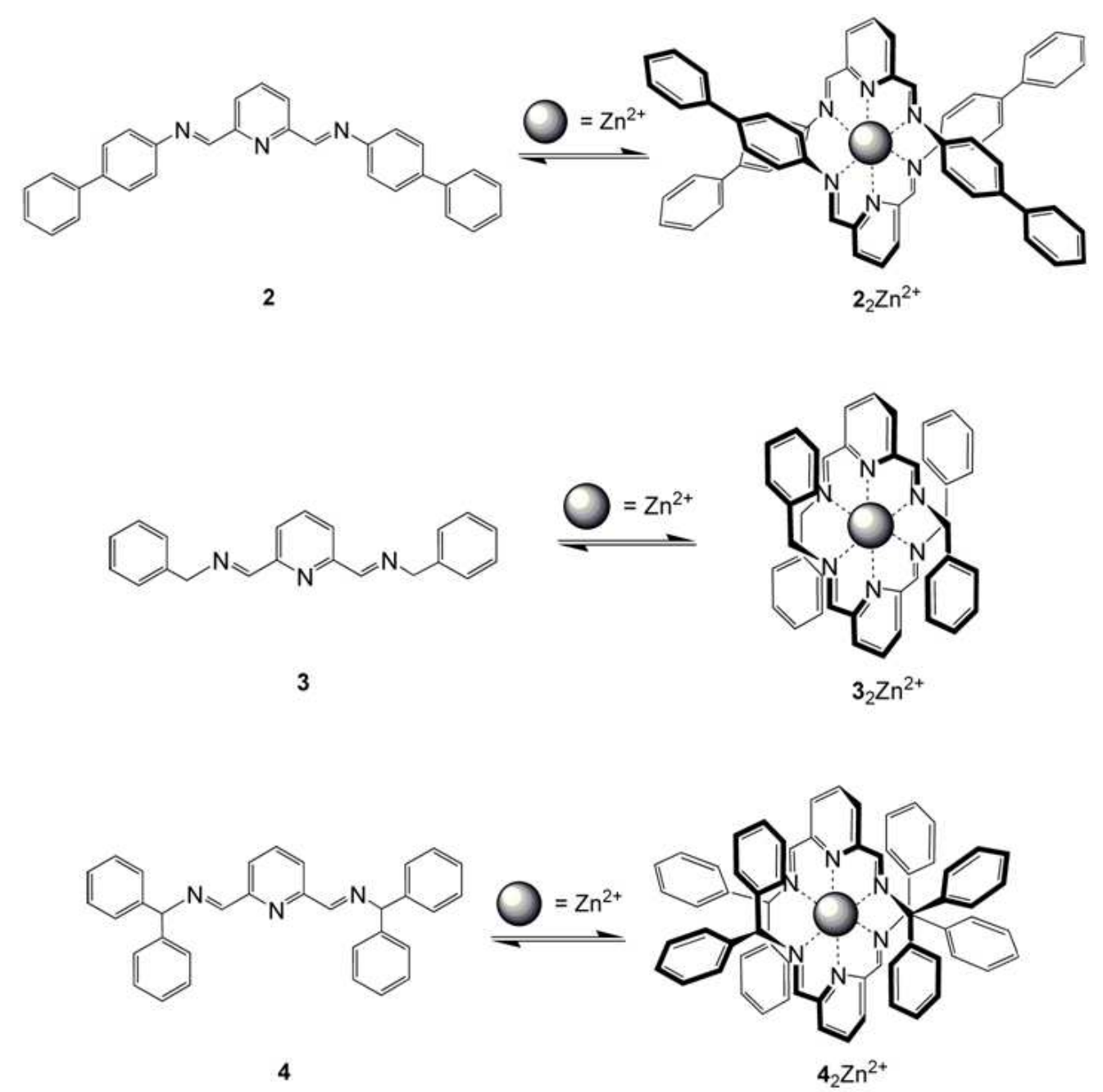

SCHEME 1 Synthesis of $22 Z n 2+, 32 Z n 2+$ and $42 Z n 2+$ duplex complexes $190 \times 194 \mathrm{~mm}(96 \times 96 \mathrm{DPI})$ 
a

2

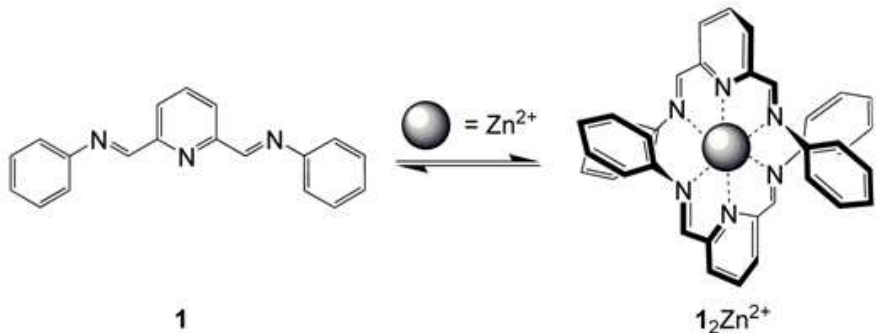

b

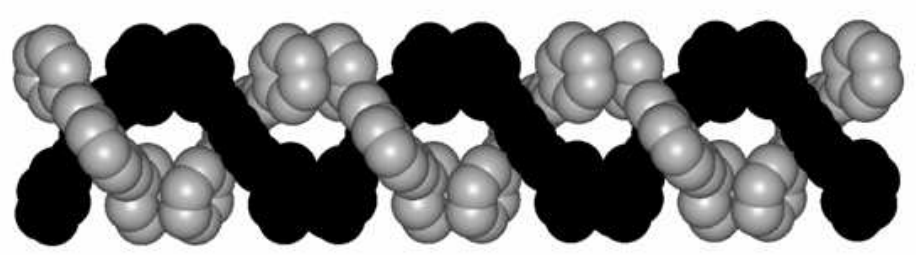

C

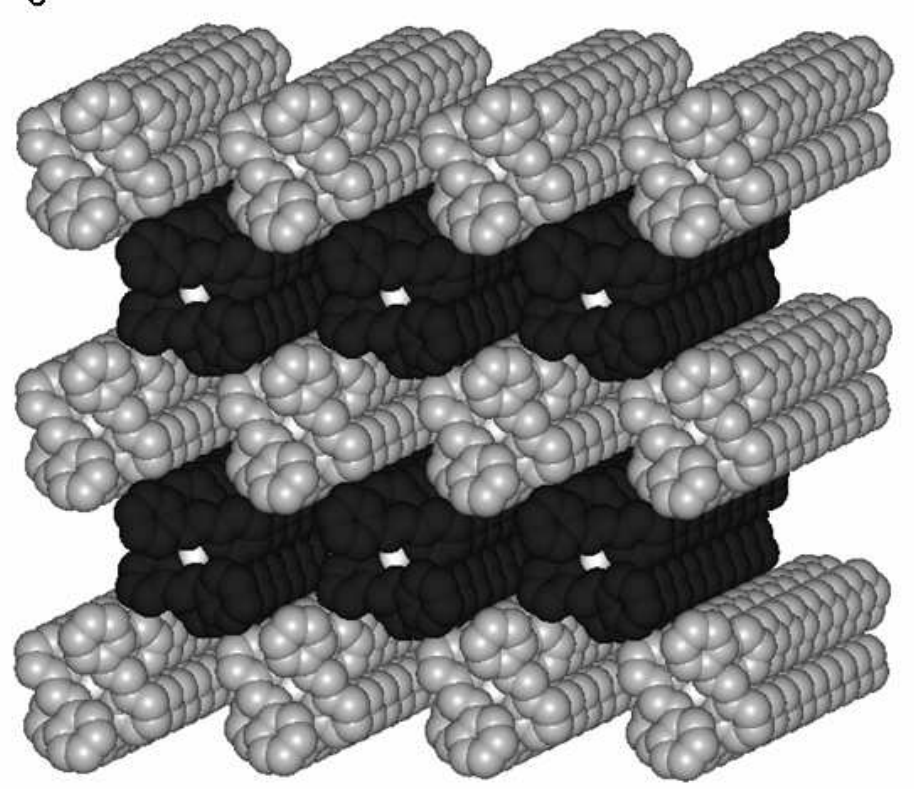

FIGURE 1. From achiral ligands to metallosupramolecular homochiral double helical strands. a) Synthesis of $12 \mathrm{Zn} 2+$ duplex complexes; b) homochiral double helix stacks of $12 \mathrm{Zn} 2+$ units and c) crystal packing of double-helix columns: generation a gearwheels-type mechanism such that each double helix is in van der Waals contact with four neighbouring ones of the same helical sense. $151 \times 245 \mathrm{~mm}(96 \times 96 \mathrm{DPI})$ 


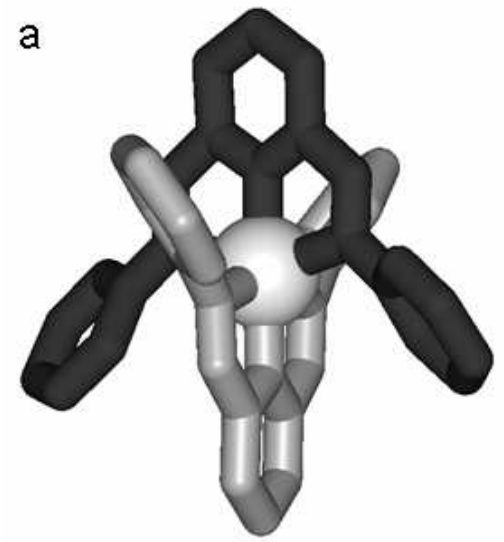

b
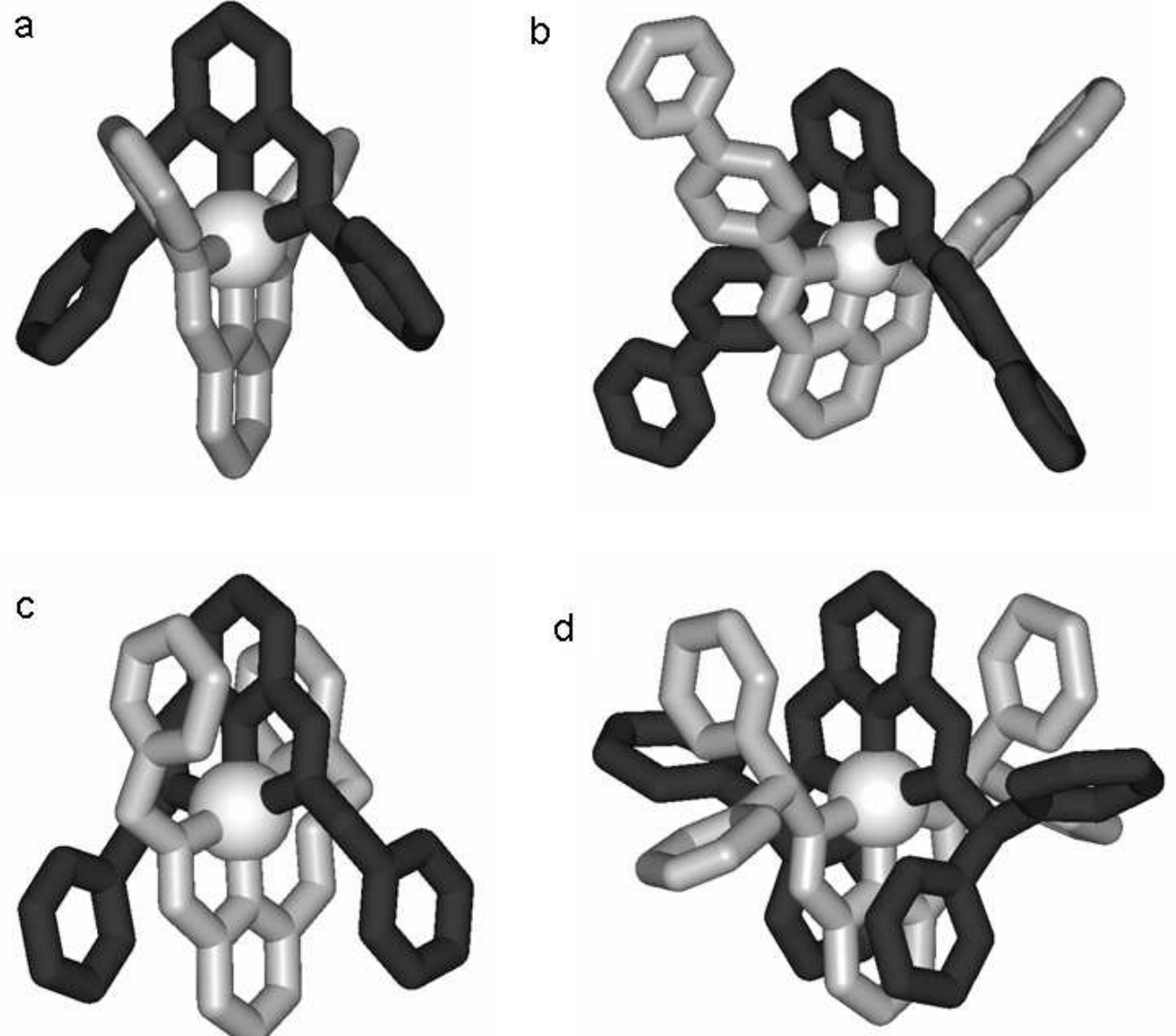

FIGURE 2. Crystal structure in stick representation of the duplex complexes a) $12 \mathrm{Zn} 2+$, b) $22 \mathrm{Zn} 2+$, c) $32 \mathrm{Zn} 2+$ and d) $42 \mathrm{Zn} 2+$; the $\mathrm{Zn} 2+$ ions are shown as white spheres. $190 \times 182 \mathrm{~mm}(96 \times 96 \mathrm{DPI})$ 

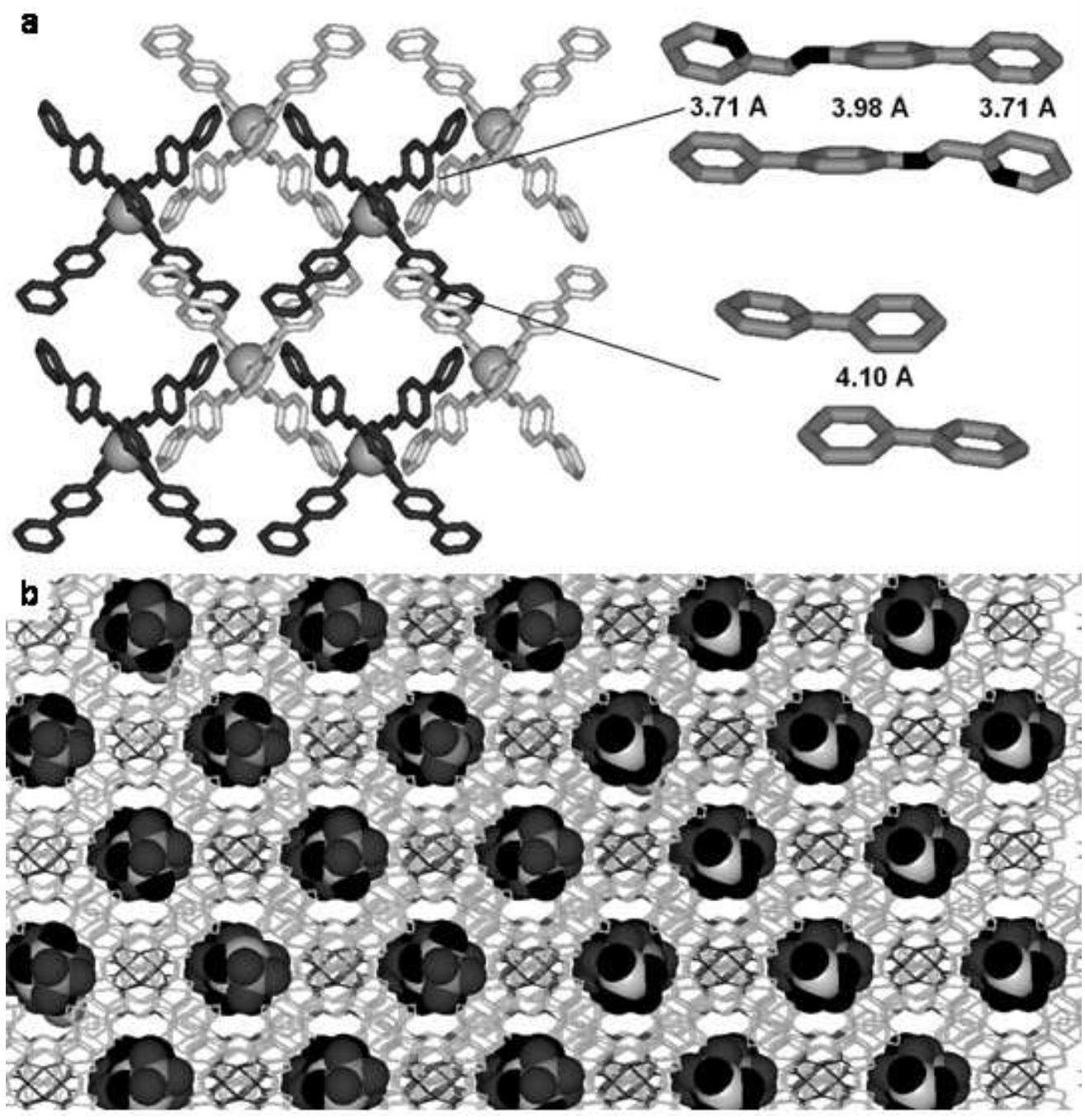

FIGURE 3 Crystal packing of the duplex complex 22Zn2+: a) side view in stick representation and enlarged details of the $\pi-\pi$ stacking interactions; b) The square packing arrangement of duplex subunits with the triflate anions in CPK representation filling the central cavity of the resulted tubular channels. The $\mathrm{Zn} 2+$ ions are shown as gray spheres. $142 \times 149 \mathrm{~mm}(96 \times 96 \mathrm{DPI})$ 

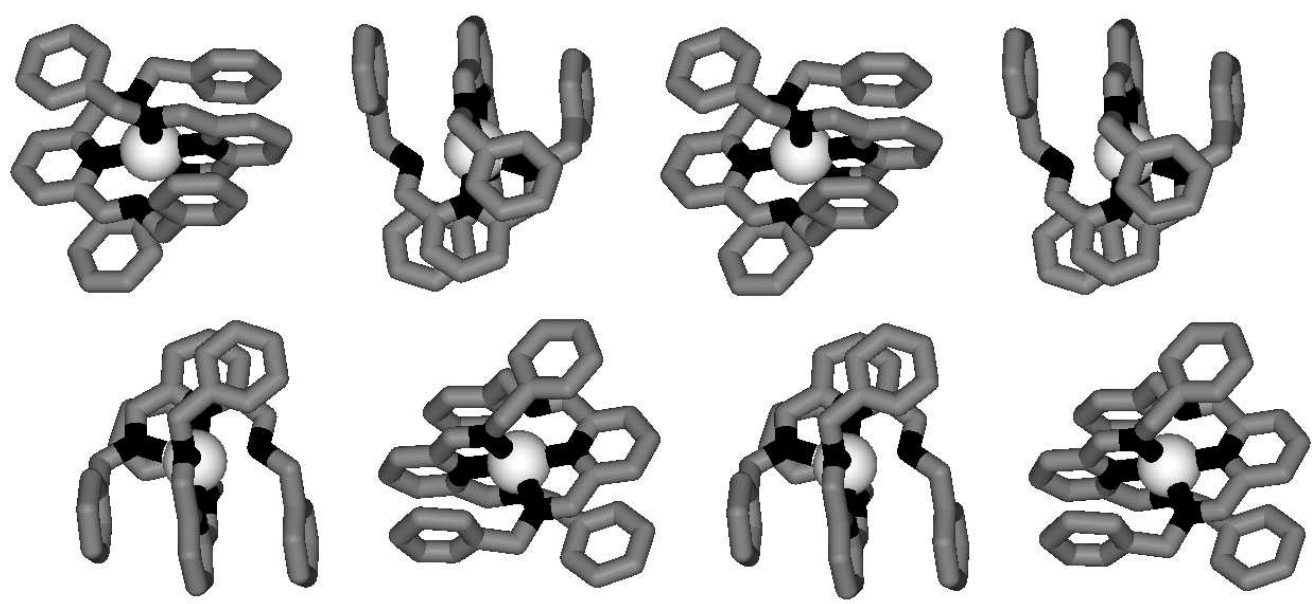

FIGURE 4 Crystal packing in stick representation of the duplex complex $32 \mathrm{Zn} 2+$. $325 \times 160 \mathrm{~mm}(96 \times 96 \mathrm{DPI})$ 


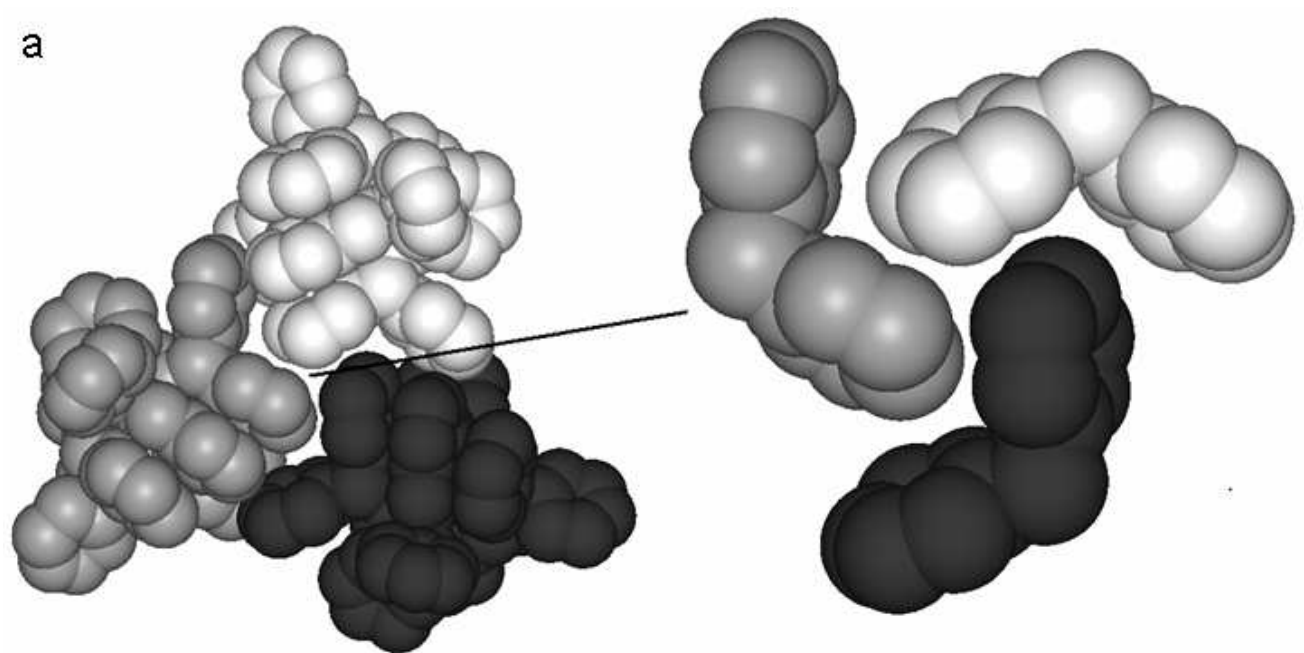

b
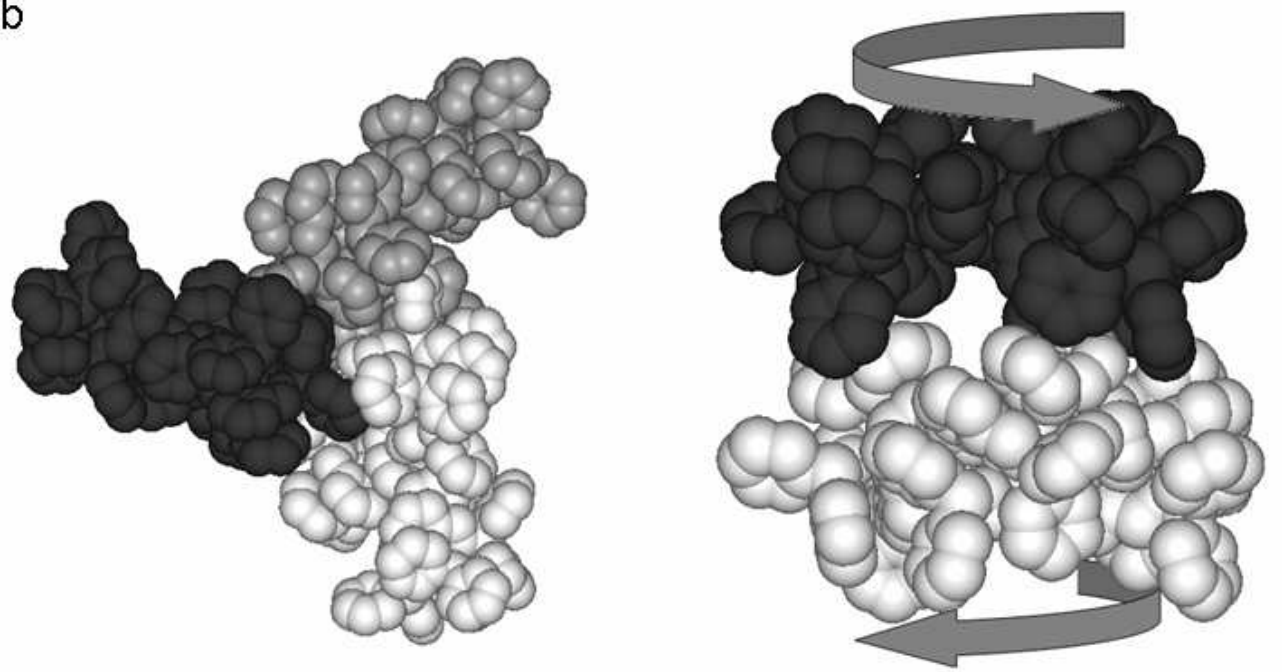

FIGURE 5 Crystal packing of the duplex complex 42Zn2+: a) side view in CPK representation of triangle like trimers and enlarged details of the ÂA diphenylmethane embrace motifÂA ; b) The packing arrangement of homochiral triangle enantiomers: top view of tetrahedral nodes and side view in CPK representation of face-to- face triangle self-assembly. $190 \times 205 \mathrm{~mm}(96 \times 96 \mathrm{DPI})$ 


\title{
Interpenetrated Constitutional Networks of Aromatic Metallosupramolecular Duplexes
}

\author{
Y.-M. LEGRAND ${ }^{\mathrm{a}}$, F. DUMITRU ${ }^{\mathrm{a}, \mathrm{b}}$, A. V. D. LEE $^{\mathrm{a}} \&$ M. BARBOIU ${ }^{\mathrm{a}, *}$ \\ ${ }^{a}$ Institut Européen des Membranes, Adaptive Supramolecular Nanosystems Group - ENSCM- \\ UMII-CNRS UMR- 5635, Place Eugène Bataillon, CC 047, F-34095 Montpellier, Cedex 5, \\ France, ${ }^{b}$ University "Politehnica” of Bucharest, Department of Inorganic Chemistry, 1 , \\ Polizu st., RO-011061 Bucharest, Romanial \\ E-mail: mihai.barboiu@iemm.univ-montp2.fr
}

\section{Supplementary Material}


$\underline{{ }^{1} \mathrm{H}-\mathrm{NMR}(\mathrm{ppm}) \text { Spectra: }}$

\section{*Compound 2}

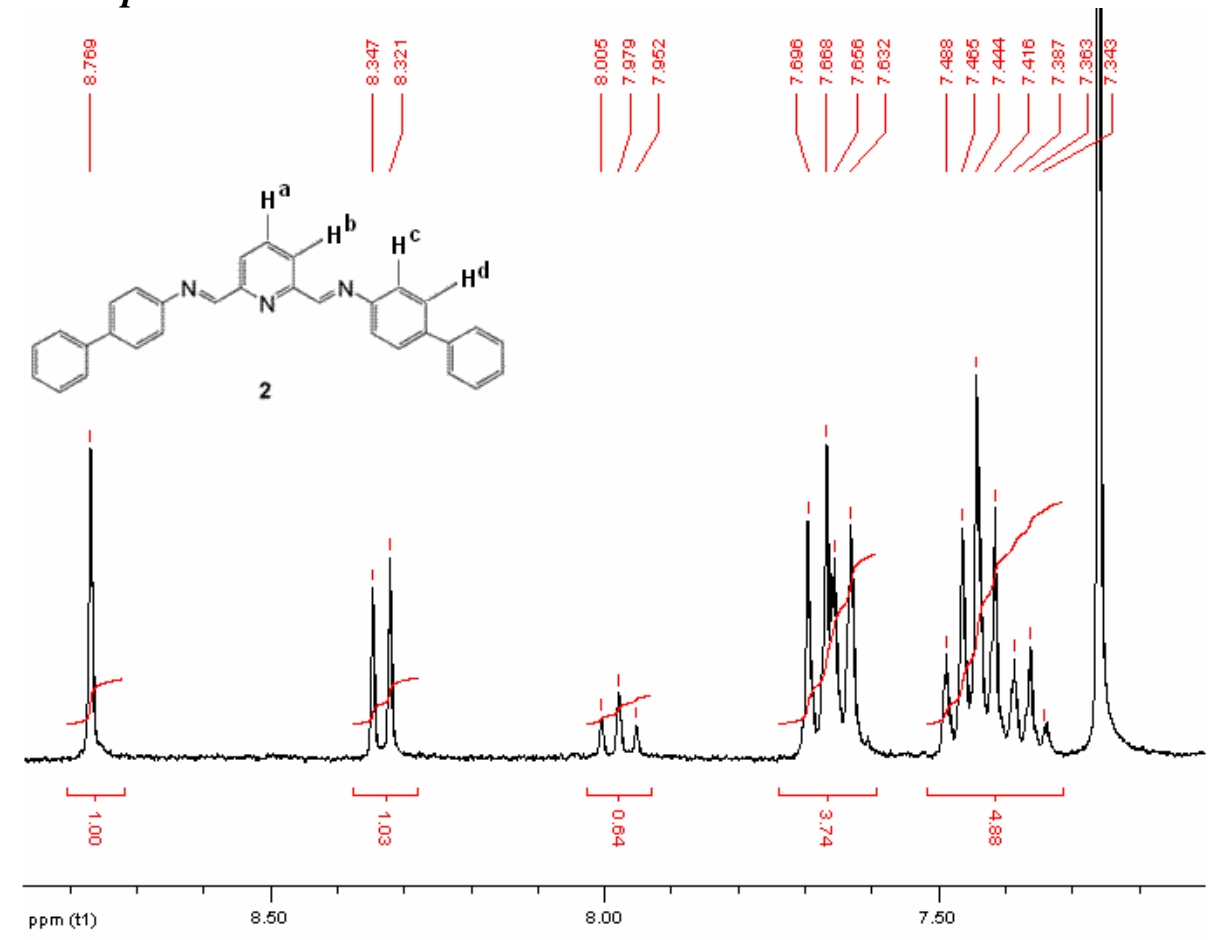

Figure 1S. ${ }^{1} \mathrm{H}$ NMR spectrum of 2 in $\mathrm{CDCl}_{3}$ at RT.

*Compound $2 \mathrm{Zn}^{2+}$

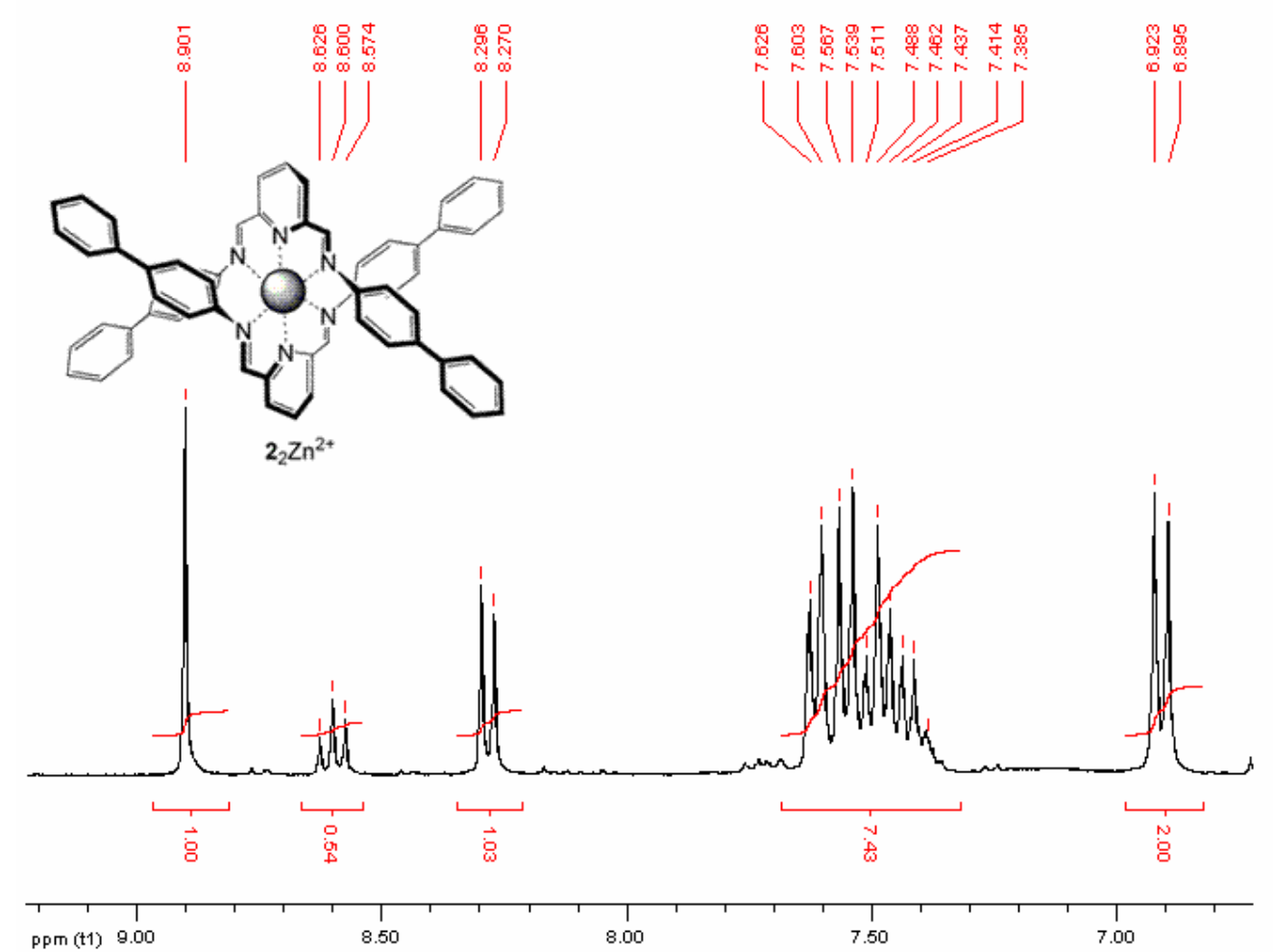

Figure $2 \mathrm{~S}$. ${ }^{1} \mathrm{H}$ NMR spectrum of $2_{2} \mathrm{Zn}^{2+}$ in $\mathrm{CD}_{3} \mathrm{CN}$ at RT. 


\section{*Compound 4}

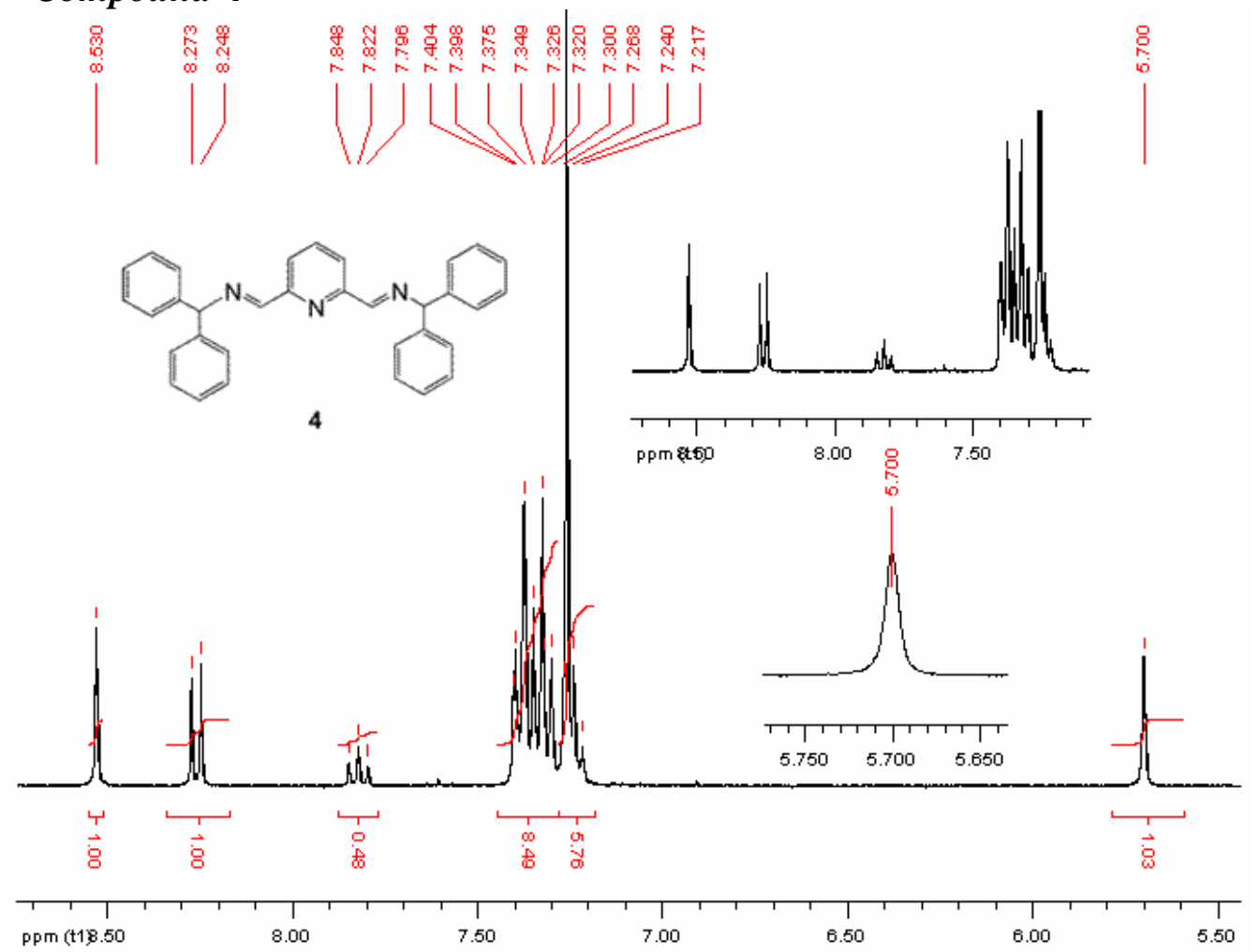

Figure 3S. ${ }^{1} \mathrm{H}$ NMR spectrum of 4 in $\mathrm{CDCl}_{3}$ at RT.

\section{*Compound $4_{2} \mathrm{Zn}^{2+}$}

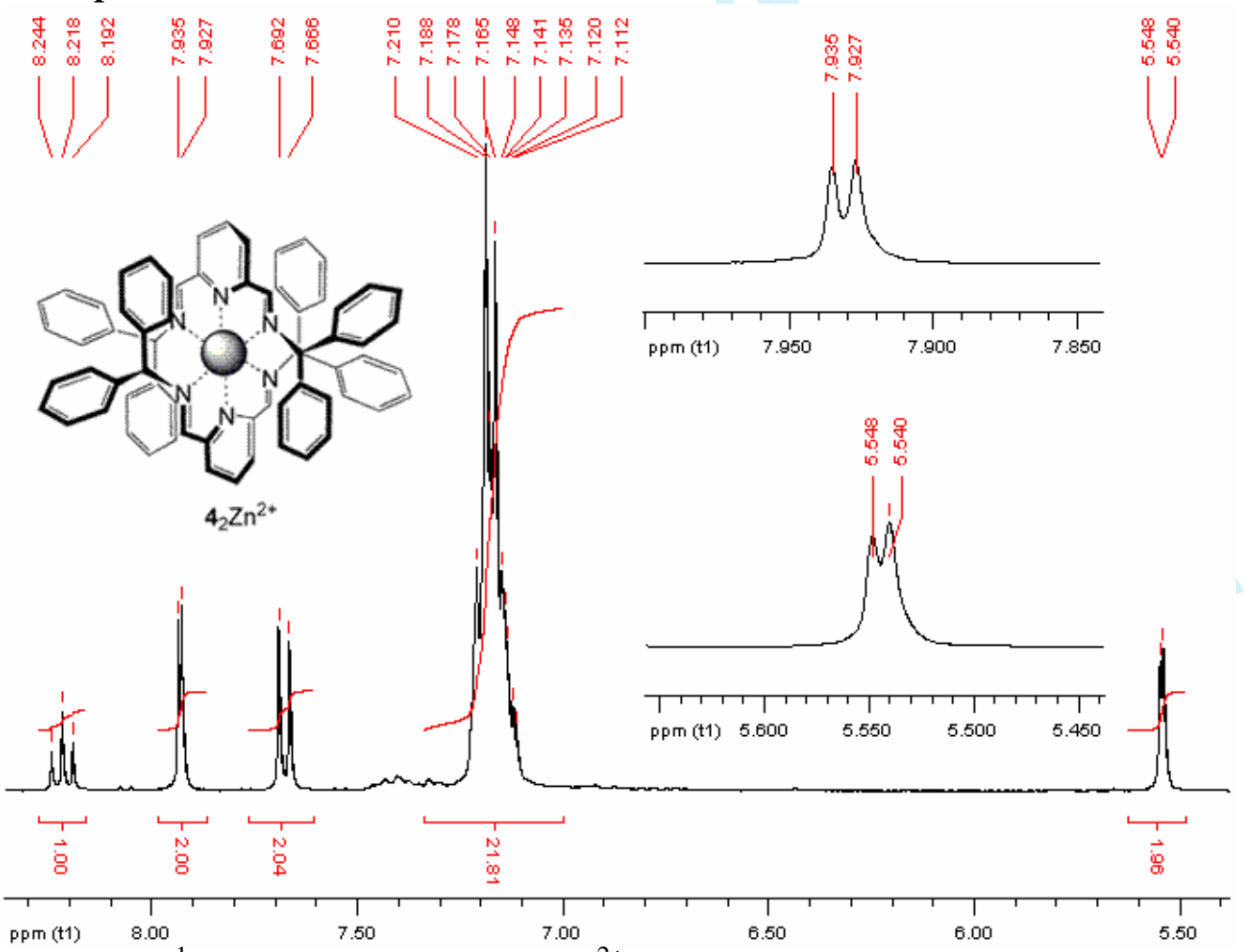

Figure $4 \mathrm{~S}$. ${ }^{1} \mathrm{H}$ NMR spectrum of $\mathbf{4}_{2} \mathrm{Zn}^{2+}$ in $\mathrm{CD}_{3} \mathrm{CN}$ at RT. 
$\underline{\text { Crystallographic Data }}$

\section{$\underline{2}_{2} \mathrm{Zn}^{2+}$ in $\mathrm{C} 2 / \mathrm{c}$}

Formula

Crystal Class

a

b

c

Volume

Radiation type

Dx

$\mathrm{Mu}$

Size

Colour

Diffractometer type

Absorption type

Reflections meas.

Rint

Hmin, Hmax

Kmin, Kmax

Lmin, Lmax
C64 H26 F6 N6 O6 S2 Zn1

Monoclinic

23.6043(4)

$15.1311(3)$

$15.5706(3)$

5560.54(18)

$\mathrm{Cu} \mathrm{Kla}$

1.48

2.004

$0.05 \mathrm{x} 0.11 \mathrm{x} 0.11$

yellow

XCALIBUR

multi-scan

19534

0.0004

$\begin{array}{ll}-26 & 25\end{array}$

$\begin{array}{ll}-13 & 16\end{array}$

$-17 \quad 16$
Space Group

alpha

beta

gamma

$\mathrm{Z}$

Wavelength

$\mathrm{Mr}$

Temp (K)

Shape

Scan type

Transmission range 0.800 .90

Independent reflect. 4033

Theta max

OMEGA
C $12 / \mathrm{c} 1$

90

90.8703(16)

90

8

1.541800

619.30

175

prismatic

4033

61.13

$\underline{\text { Refinement on F2 }}$

\begin{tabular}{llll}
\hline R-factor & 0.038 & Weighted R-factor & 0.074 \\
Max shift/su & 0.0002 & Delta Rho max & 0.43 \\
Delta Rho min & -0.37 & sigma(I) limit & 2.00 \\
Reflections used & 3010 & Goodness of fit & 1.036
\end{tabular}

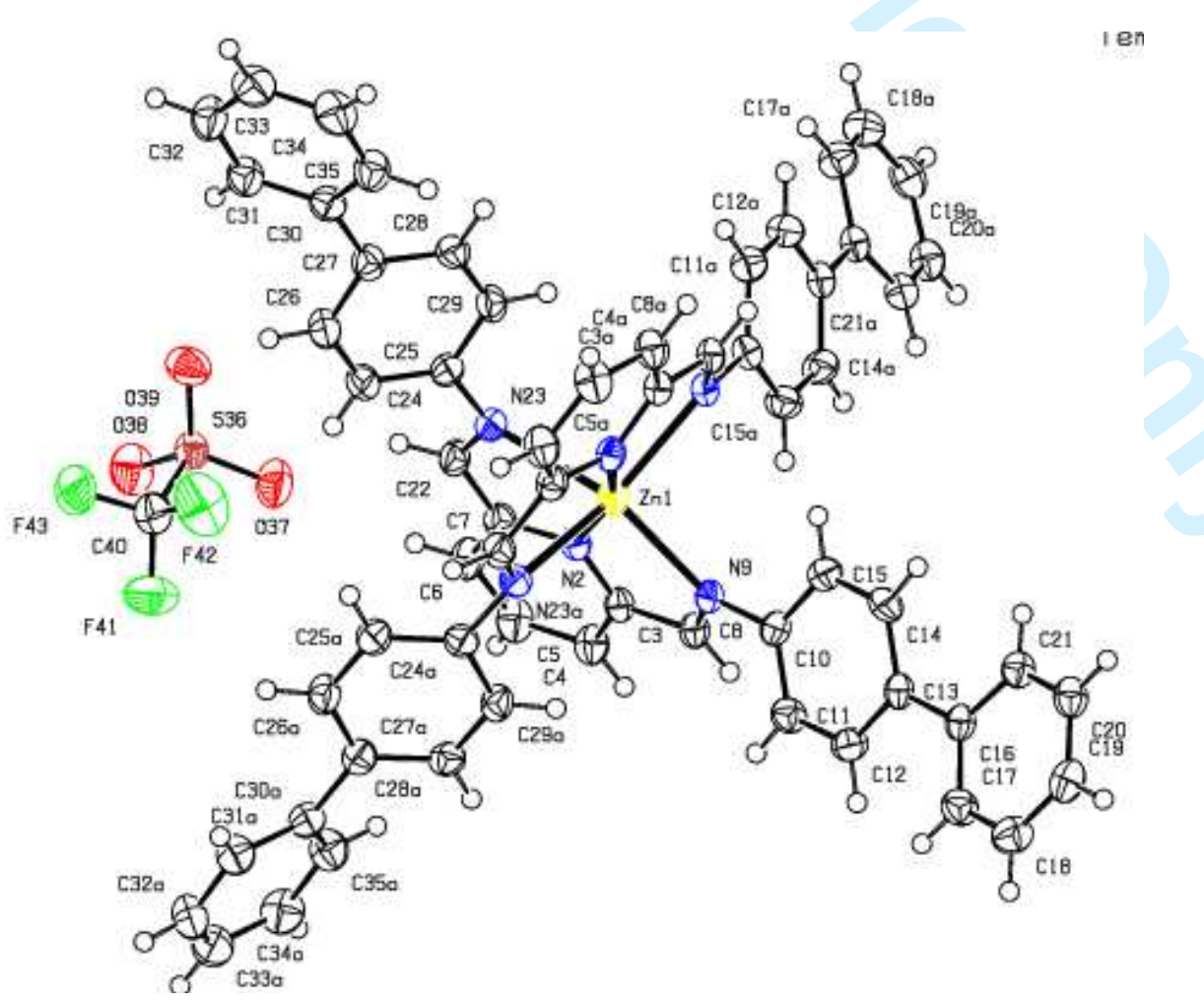




\section{$\underline{3}_{2} \mathrm{Zn}^{2+}$ in $\mathrm{P} 21 / \mathrm{c}$}

Formula

Crystal Class

a

b

c

Volume

Radiation type

Dx

$\mathrm{Mu}$

Size

Colour

Diffractometer type

Absorption type

Reflections meas.

Rint

Hmin, Hmax

Kmin, Kmax

Lmin, Lmax

Refinement on $\mathrm{F}$
C44 H38 F6 N6 O6 S2 Zn1

$\begin{array}{lll}\text { Monoclinic } & \text { Space Group } & \text { P } \quad \text { 21/c 1 } \\ 17.854 & \text { alpha } & 90 \\ 14.078 & \text { beta } & 111.72 \\ 18.612 & \text { gamma } & 90 \\ 4345.9712(3) & \text { Z } & 4 \\ \text { Mo Kla } & \text { Wavelength } & 0.710730 \\ 1.51 & \text { Mr } & 990.32 \\ 0.743 & \text { Temp (K) } & 175\end{array}$

0.09 x $0.11 \times 0.17$

yellow

XCALIBUR

multi-scan

85283

0.0012

$\begin{array}{ll}-26 & 26\end{array}$

$\begin{array}{ll}-20 & 20\end{array}$

$\begin{array}{ll}-27 & 27\end{array}$
Shape prismatic

Scan type OMEGA

Transmission range 0.920 .94

Independent reflect. 14420

Theta max $\quad 32.57$

$\begin{array}{llll}\text { R-factor } & 0.049 & \text { Weighted R-factor } & 0.044 \\ \text { Max shift/su } & 0.0384 & & \\ \text { Delta Rho min } & -0.46 & \text { Delta Rho max } & 0.81 \\ \text { Reflections used } & 4862 & \text { sigma(I) limit } & 2.00 \\ \text { Nb of parameters } & 586 & \text { Goodness of fit } & 1.137\end{array}$

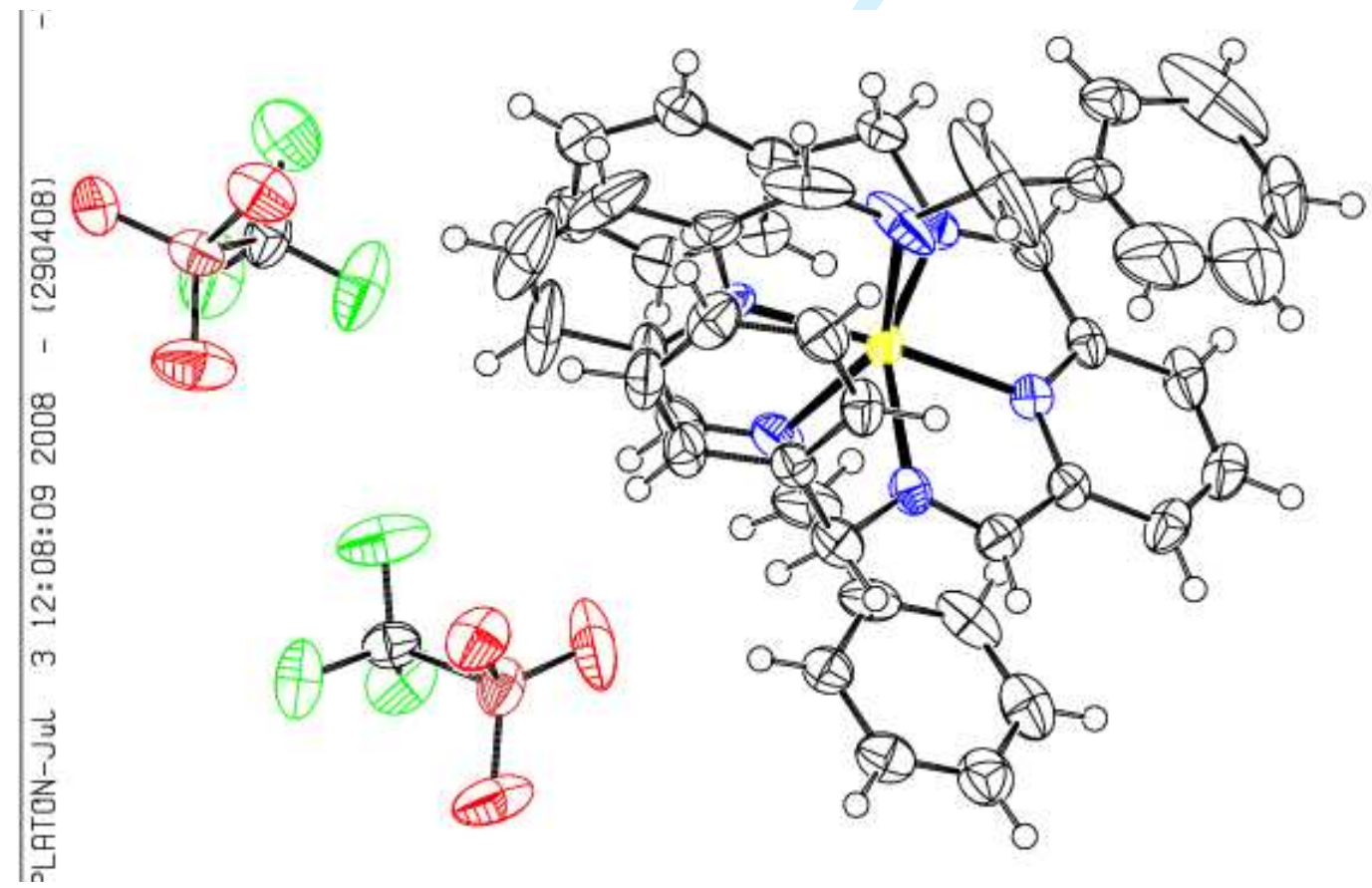




\section{$\underline{4} 2 \mathrm{Zn}^{2+}$ in $\mathrm{I}-43 \mathrm{~d}$}

Formula

Crystal Class

a

b

c

Volume

Radiation type

Dx

$\mathrm{Mu}$

Size

Colour

Diffractometer type

Absorption type

Reflec. measured

Rint

Hmin, Hmax

Kmin, Kmax

Lmin, Lmax

Refinement on $\mathrm{F}$

$\begin{array}{lll}\text { R-factor } & & 0.165 \\ \text { Max shift/su } & & 6.7134 \\ \text { Delta Rho min } & -0.75 \\ \text { Reflections used } & 836 \\ \text { Nb of parameters } & 104\end{array}$

C70 H58 F12 N6 O10 S2 Zn1

\begin{tabular}{|c|c|c|}
\hline Cubic & Space Group & $\begin{array}{llll}\mathrm{I} & -4 & 3 & \mathrm{~d}\end{array}$ \\
\hline $27.337(2)$ & alpha & 90 \\
\hline $27.355(2)$ & beta & 90 \\
\hline $27.362(2)$ & gamma & 90 \\
\hline 20461(3) & $\mathrm{Z}$ & 12 \\
\hline Mo Kla & Wavelength & 0.710730 \\
\hline 1.46 & $\mathrm{Mr}$ & 375.19 \\
\hline 0.518 & Temperature (K) & 175 \\
\hline
\end{tabular}

$0.06 \mathrm{x} 0.12 \times 0.12$

colorless

Shape

prismatic

Scan type OMEGA

Transmission range 0.940 .97

Independent reflect. 5976

Theta max

32.42
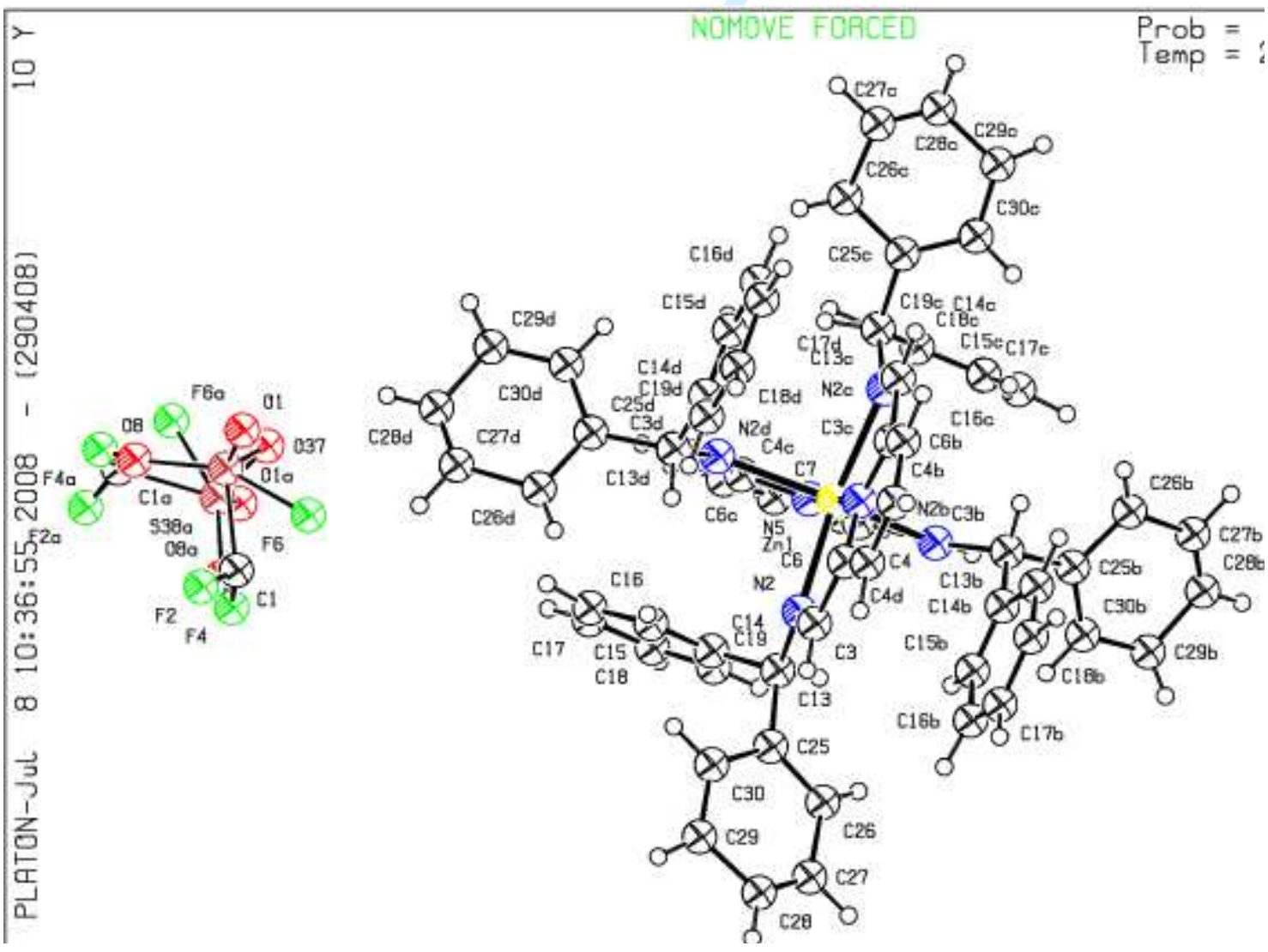